\title{
PERAN GURU AQIDAH AKHLAK DALAM MENANGGULANGI KENAKALAN SISWA DI MTS HIDAYATUS SHOLIHIN TURUS
}

\author{
Agus Miftakus Surur \\ Institut Agama Islam Negeri Kediri \\ surur.math@gmail.com \\ Titis Dwi Wulandari \\ Institut Agama Islam Negeri Kediri \\ titis.wulan25@gmail.com \\ Tanya Fawzi \\ Institut Agama Islam Negeri Kediri \\ tanya.fawri96@gmail.com \\ Adib Zaimatus Shofa \\ Institut Agama Islam Negeri Kediri \\ adibraimatusshofa@gmail.com
}

\begin{abstract}
Abstrak
Guru memiliki peran yang sangat penting dalam menanggulangi kenakalan yang terjadi pada siswa, dan berperan membentuk akhlak yang baik bagi siswa. Penelitian ini bertujuan untuk mengetahui faktor penyebab kenakalan siswa dan untuk mengetahui peran guru dalam menanggulangi kenakalan siswa kelas VIII di MTs Hidayatus Sholihin Turus (Gurah). Penelitian ini menggunakan data sebagai informasi yang lengkap dan mendalam mengenai peran guru aqidah akhlak dalam menanggulangi kenakalan siswa kelas VIII di MTs Hidayatus Sholihin Turus (Gurah) sehingga metode yang sesuai digunakan dalam penelitian ini adalah metode kualitatif. Hasil penelitian menunjukkan bahwa faktor yang mempengaruhi kenakalan siswa adalah faktor lingkungan dan pengaruh dari teman-temannya. Jenis pelanggaran yang sering dilakukan adalah merokok, membolos, dan pulang sebelum waktunya. Sementara itu guru aqidah akhlak memiliki peran dalam menanggulangi kenakalan siswa melalui proses pembelajaran dengan mengaitkan antara bab yang dipelajari dengan kehidupan sehari-hari dan bekerja sama dengan guru lainnya untuk mengambil suatu tindakan atau untuk memanggil orang tua apabila terdapat siswa yang melakukan pelanggaran cukup berat.
\end{abstract}

Kata Kunci : Peran Guru, Aqidah Akblak, Kenakalan Siswa

\section{Abstract}

Teachers have a very important role in overcoming delinquency that occurs in students, and play a role in forming good morals for students. This study aims to determine the factors 


\section{Agus Miftakus Surur, Titis Dwi Wulandari, Tanya Fawzi, Adib Zaimatus Shofa}

causing student delinquency and to determine the teacher's role in tackling the delinquency of class VIII students at MTs Hidayatus Sholihin Turus (Gurah). This study uses data as complete and in-depth information about the role of aqidah moral teachers in overcoming delinquency in class VIII students at MTs Hidayatus Sholihin Turus (Gurah) so that the appropriate method used in this study is a qualitative method. The results showed that the factors that influence student delinquency are environmental factors and the influence of their friends. The types of violations that are often carried out are smoking, truancy, and coming home prematurely. Meanwhile, the Aqidah Morals teacher has a role in tackling student delinquency through the learning process by linking the chapters studied with everyday life and collaborating with other teachers to take an action or to call parents if there are students who commit serious violations.

Keywords: Teacher's Role, Moral Aqidah, Student Delinquency

\section{Pendahuluan}

Pendidikan merupakan salah satu pilar dan modal utama dalam menyongsong masa depan, karena pendidikan selalu diorientasikan untuk mengembangkan sumber daya peserta didik guna dapat berperan di masa yang akan datang dan diarahkan kepada kebutuhan manusia ${ }^{1}$. Hal ini sesuai dengan apa yang diamanatkan pemerintah dalam UU Sistem Pendidikan Nasional No. 20 tahun 2013 , bahwa tujuan pendidikan nasional berfungsi untuk mengembangkan kemampuan dan membentuk watak serta peradaban bangsa yang bermartabat dalam rangka mencerdaskan kehidupan bangsa, dan bertujuan untuk berkembangnya potensi peseta didik agar menjadi manusia yang beriman dan bertaqwa kepada Tuhan Yang Maha Esa, berakhlak mulia, sehat, berilmu,

${ }^{1}$ Latifah Husien, Profesi Keguruan (Yogyakarta: Pustaka Baru Press, 2016)., h. 11-12. cakap, kreatif, mandiri, dan menjadi warga negara yang demokratis serta bertanggung jawab.

Di sini peran untuk membentuk karakter siswa yang tidak dapat diabaikan dalam dunia pendidikan adalah seorang guru. Guru sebagai pendidik ataupun pengajar merupakan faktor penentu kesuksesan setiap usaha pendidikan². Guru merupakan panutan bagi seorang peserta didik dalam bersikap. Seorang guru memiliki peran yang sangat penting dalam menanggulangi kenakalan yang terjadi pada siswa, dan berperan membentuk akhlak yang baik bagi siswa ${ }^{3}$. Terutama seorang guru mata pelajaran Aqidah Akhlak.

2 Muhibbin Syah, Psikologi Pendidikan Dengan Pendekatan Baru (Bandung: Remaja Rosdakarya, 2010)., h. 180

3 Agus Miftakus Surur, "Peningkatan Kemampuan Khatabah (Public Speaking Skill) Santri Ma'had Darul Hikmah IAIN Kediri," Ijaz Arabi Journal of Arabic Learning 1, no. 2 (2018)., h. 16. 
Aqidah akhlak berasal dari dua kata aqidah dan akhlak. Aqidah berakar dari kata yang berarti tali pengikat sesuatu dengan yang lain, sehingga menjadi satu kesatuan yang tidak dapat dipisahkan. Sedangkan Pengertian akhlak secara etimologi berasal dari kata "Khuluq" dan jama'nya "Akhlaq", yang berarti budi pekerti, etika, moral. Imam Ghozali mengemukakan definisi akhlak sebagai suatu sifat yang tertanam dalam jiwa yang dari padanya timbul perbuatan-perbuatan dengan mudah, dengan tidak memerlukan pertimbangan pikiran (lebih dahulu) ${ }^{4}$. Jadi dapat disimpulkan bahwa aqidah akhlak adalah wahana pemberian pengetahuan, meyakini dan menghayati kebenaran agama Islam serta bersedia mengamalkan dalam kehidupan sehari-hari.

Sehubungan dengan hal tersebut, hal yang terpenting ditanamkan pada setiap siswa adalah menanamkan dan membina akhlak sedini mungkin ${ }^{5}$. Hal tersebut perlu mengingat banyaknya kenakalan siswa yang terjadi pada saat ini. menurut Kartini Kartono, Juvenil delinquency ialah perilaku jahat atau kenakalan anak-anak muda. Hal ini merupakan gejala sakit (patologis) secara sosial pada anak-anak dan remaja yang

\footnotetext{
${ }^{4}$ Mustofa, Akblak Tasawnf (Bandung: Pustaka Setia, 2011)., h. 197.

5 Hibana S. Rahman, Konsep Dasar Pendidikan Anak Usia Dini (Yogyakarta: PGTKI Press, 2002)., h. 24.
}

disebabkan oleh suatu bentuk tingkah laku yang menyimpang ${ }^{6}$. Seperti yang terjadi di MTs hidayatus Sholihin siswa kelas VIII terdiri dari empat kelas, di madrasah ini hal yang menurut penulis unik adalah kelas siswa laki-laki dan perempuan sendiri-sendiri. Hal ini menjadi sesuatu yang unik karena cukup jarang sekolah yang menerapkan sistem seperti ini.

Meskipun memiliki keunikan tetapi disisi lain terdapat berbagai kenakalan yang dilakukan oleh siswa kelas VIII, salah satunya adalah dibidang kedisiplinan. Sebagai seorang guru Aqidah Akhlak yang selalu mengajarkan tentang tata krama, guru Aqidah Akhlak selalu memberikan nasihat-nasihat kepada siswanya untuk tidak bersikap yang tidak baik. ketika masuk waktu pembelajaran guru mengaitkan mata pelajaran dengan kenyataan yang terjadi, sehingga hal tersebut secara tidak langsung mendidik para siswanya untuk menanggulangi kenakalan yang terjadi pada siswa kelas VIII. Selain itu guru Aqidah Akhlak di MTs Hidayatus Sholihin juga menjadi wakil kesiswaan atau Wakasis.

$$
\text { Sehingga beliau memahami }
$$
permasalahan dan kenakalan yang terjadi pada siswa kelas VIII. Guru Aqidah Akhlak dalam menanggulangi kenakalan siswa yaitu ketika di dalam kelas guru mengaitkan mata

\footnotetext{
${ }^{6}$ Kartini Kartono, Kenakalan Remaja (Jakarta: Raja Grafindo Persada, 2013)., h. 49.
} 


\section{Agus Miftakus Surur, Titis Dwi Wulandari, Tanya Fawzi, Adib Zaimatus Shofa}

pelajaran Aqidah Akhlak dengan kenyataan yang berkaitan dengan kenakalan yang terjadi, sehingga siswa menjadi berpikir dan memahami akibat yang akan diterima ketika melanggar norma yang ada.

Ketika di luar kelas guru bersikap seperti teman dan juga orang tua serta selalu menanyakan apa yang terjadi dan apakah semua baik-baik saja. Sehingga siswa merasa diperhatikan dan ketika mereka ada masalah mereka dapat mengatakannya dan mencari solusi bukan malah memilih untuk menjadi anak yang suka melanggar norma. Perhatian yang diberikan oleh guru dapat membuat siswa merasa dihargai ${ }^{7}$. Berdasarkan uraian tersebut, penulis tertarik untuk mengambil judul "Peran Guru Aqidah akhlak dalam Menanggulangi Kenakalan Siswa di MTs Hidayatus Sholihin Turus (Gurah)”.

\section{Metodologi Penelitian}

Berdasarkan permasalahan yang dikemukakan di atas, penelitian ini berusaha untuk mendapatkan informasi yang lengkap dan mendalam mengenai peran guru aqidah akhlak dalam menanggulangi kenakalan siswa kelas VIII di MTs Hidayatus Sholihin Turus (Gurah). Maka peneliti mencoba menggunakan jenis penelitian kualitatif. Metode yang digunakan dalam penelitian ini adalah metode kualitatif. Penelitian kualitatif

7 Agus Miftakus Surur, Ragam Strategi Pembelajaran Dilengkapi Dengan Evaluasi Formatif (Banten: CV. AA. Rizky, 2020)., h. 5. adalah suatu penelitian yang ditujukan untuk mendeskripsikan dan menganalisis fenomena, peristiwa, aktivitas sosial, sikap, kepercayaan, persepsi, pemikiran orang secara individual maupun kelompok ${ }^{8}$.

Berdasarkan judul di atas "Peran Guru Aqidah akhlak Dalam Menanggulangi Kenakalan Siswa Kelas VIII di MTs Hidayatus Sholihin Turus (Gurah)" dianggap sebagai penelitian kualitatif karena penelitian ini tidak bersifat menguji kebenaran suatu teori, melainkan untuk menarik kesimpulan gejala yang terjadi di MTs Hidayatus Sholihin Turus (Gurah).

Implikasi penanaman nilai-nilai dasar agama Islam terhadap perilaku anak baik di rumah maupun di sekolah menunjukkan adanya implikasi yang signifikan?. Penelitian tersebut dilakukan pada siswa TK. Durasi yang dilakukan dalam Pendidikan di sekolah singkat, sehingga perlu pendampingan juga di rumah masing. Sedangkan pada penelitian ini pada siswa MTs yang dalam durasinya cukup lama dalam madrasah, sehingga perlu ikut serta peran guru dalam membimbing siswa.

Pembelajaran fiqih yang berhasil menanamkan sikap saling menghargai dan

8 Bachtiar S. Bachri, "Meyakinkan Validitas Data Melalui Triangulasi Pada Penelitian Kualitatif," Jurnal Teknologi Pendidikan 1, no. 1 (2010). h. 17.

9 St. Rodliyah, "Implikasi Penanaman NilaiNilai Dasar Agama Islam Terhadap Perilaku Anak Di Taman Kanak-Kanak (TK) 'Al-Amien' Kabupaten Jember," An-Nisa': Jurnal Kajian Perempuan \& Keislaman 13, no. 2 (2020). h. 353. 
menghormati, toleransi dan tidak saling menyalahkan ini dapat melahirkan generasigenerasi Islam yang baru yang dapat diterima oleh semua kalangan dalam massyarakat. Dengan demikian ukhuwah Islamiyah pasti terjalin $^{10}$. Dalam penelitian tersebut guru fiqih memberikan perannya sesuai dengan materi yang diajarkan. Begitu juga dalam penelitian ini, guru akidah akhlak berupaya mengimplementasikan pelajaran yang diajarkan di kelas untuk di terapkan dilingkungan madrasah. Hal itu diharapkan memberikan dampak yang signifikan pada diri siswa.

\section{Pembahasan}

Faktor Penyebab Kenakalan Siswa Kelas VIII Di MTs Hidayatus Sholihin Turus

Berdasarkan hasil wawancara dengan berbagai pihak diantaranya dengan kepala sekolah dan guru aqidah akhlak, dapat dimasukkan kepada pokok persoalan yang kedua mengenai jenis pelanggaran yang sering dilakukan oleh siswa kelas VIII MTs Hidayatus Sholihin Turus (Gurah). Menurut Ibu Ainun Choiriyah selaku guru mata pelajaran aqidah akhlak ketika diwawancarai tentang jenis pelanggaran yang sering

10 Muhamad Nuril Huda, "Profesionalisme Guru Fiqih Dalam Pembelajaran Dan Implikasinya Terhadap Sikap Keberagamaan Siswa Di MTs Negeri Kota Manado," An-Nisa' : Jurnal Kajian Perempuan \& Keislaman 13, no. 1 (2020). h. 113. dilakukan oleh siswa kelas VIII MTs Hidayatus Sholihin Turus (Gurah) mengatakan bahwa:

Pertama anak putra merokok, terus yang kedua sering meninggalkan jam pelajaran, pada jam pelajaran yang terakhir, sedangkan yang anak putri tidak ada masalah. Seringnya merokok, ketahuan merokok di warung pada jam istirahat ${ }^{11}$.

Dari keterangan Ibu Ainun Choiriyah diatas, peneliti mengambil kesimpulan bahwa jenis pelanggaran yang sering dilakukan oleh siswa kelas VIII adalah bahwa para siswa lakilaki sering merokok dan pulang pada saat jam pelajaran yang terakhir padahal belum waktunya untuk pulang. Hal tersebut merupakan bagian dari kenakalan siswa. Kebiasaan seperti ini perlu segera ditindaklanjuti karena dapat merambah keberbagai aspek ${ }^{12}$. Kenakalan berasal dari kata "nakal" yang berarti kurang baik (tidak menurut dan sebagainya) terutama pada anakanak atau remaja ${ }^{13}$. Istilah kenakalan dalam Bahasa asing disebut "Delinquency" yang

11 Ainun Choiriyah, Guru Aqidah Akblak (Yogyakarta: Ruang Kepala Sekolah, 2018)., h. 15

12 Agus Miftakus Surur et al., "Problematika Pembelajaran Siswa MTs Sunan Gunung Jati (Studi Kasus Latar Belakang Siswa Menghadapi Ujian)," Edudeena 1, no. 1 (2018): h. 13-32.

13 Depdiknas, Kamus Besar Babasa Indonesia, Jakarta (Jakarta, 2007). h. 75. 


\section{Agus Miftakus Surur, Titis Dwi Wulandari, Tanya Fawzi, Adib Zaimatus Shofa}

artinya kejahatan, pelanggaran ${ }^{14}$. Sedangkan untuk siswa perempuan sendiri tidak terdapat jenis pelanggaran yang dilakukan, walaupun demiakian perlu untuk dipertahankan karena kebersamaan dengan siswa laki-laki dalam belajar tetap berlangsung ${ }^{15}$. Siswa laki-laki merokok pada saat jam istirahat dan dilakukan di warung yang berada di depan sekolah.

Selanjutnya peneliti bertanya kembali tentang faktor penyebab kenakalan siswa kelas VIII di MTs Hidayatus Sholihin menurut Ibu Ainun Choiriyah yaitu:

Faktor lingkungan, sekarang kita tahu bahwa anak-anak usia MTs merupakan usia coba-coba penasaran kenapa tidak boleh, biasanya anak-anak merokok itu kan dari lingkungan rumah hampir semua sudah lek gak ngrokok gak lanang dadine kan jajal (kalua tidak merokok bukan laki-laki, oleh sebab itu makanya coba). Terus yang kedua yang meninggalkan pelajaran itu kendalanya yang dari SD itu kan masih banyak yang belum bisa maknani jadi takut. Memang sengaja ditinggalkan soalnya takut belum bisa maknani, padahal sudah kelas VIII tapi masih ada beberapa yang belum bisa maknani, kadang ya kadang arek-arek ada yang takut

14 Hassan Shadily Jhon M. Echols, Kamus Inggris-Indonesia (Jakarta: Gramedia Pustaka Utama, 2005). h. 13.

15 Agus Miftakus Surur, Eka Septiarini, and Ayu Yulia Trianawati, "Upaya Menanamkan Nilai Religius Siswa Di MAN Kediri 1 Kota Kediri Melalui Ekstrakurikuler Keagaman Tahfidz Al-Qur'an," Jurnal Pendidikan Agama Islam XV, no. 1 (2018). h. 45. lek waktune cak Man itukan lek ada A nya sekali dalam satu minggu mesti dijejer, arekarek kan isin lek dijejer, akhirnya memilih tidak masuk ${ }^{16}$.

Berdasarkan penjelasan di atas dapat disimpulkan bahwa faktor dari kenakalan siswa yaitu disebabkan oleh faktor lingkungan yang mempengaruhi siswa. Pergaulan yang salah bukan semata-mata terjadi karena ulah anak-anak muda yang masih mentah, tetapi banyak faktor-faktor lain yang mendukung, bahkan tidak jarang ikut menghanyutkan mereka ke lembah kenistaan ${ }^{17}$. Posisi seorang teman mempunyai peran penting seperti dalam bentuk gang atau kelompok, maka besar kemungkinan anak ikut nakal ${ }^{18}$. Apalagi siswa MTs merupakan usia coba-coba rasa ingin tahu yang cukup besar didukung oleh lingkungan yang mempengaruhi seperti kalau tidak merokok tidak disebut sebagai seorang laki-laki.

Selain itu, terkait dengan banyaknya siswa yang membolos pada jam terakhir disebabkan karena banyak siswa yang belum bisa maknani. Maknani adalah menulis arab kecil-kecil miring pada kitab yang biasanya dilakukan oleh santri yang berada di pondok pesantren. Membolos dapat diartikan sebagai perilaku siswa yang tidak masuk sekolah dengan alasan yang tidak tepat atau bisa

\footnotetext{
${ }^{16}$ Jhon M. Echols, Kamus Inggris-Indonesia. h. 12.

${ }^{17}$ Hasan Basri, Remaja Berkualitas (Yogyakarta: Mitra Pustaka, 2004)., h. 145.

${ }^{18}$ Hasan Basri., Remaja Berkualitas, h. 145
} 
dikatakan ketidakhadiran tanpa alasan yang jelas ${ }^{19}$. Selain itu, bagi siswa yang terdapat A pada absensinya mereka takut untuk masuk pelajaran karena tidak mau dihukum dengan berdiri di depan kelas. Hal itu disebabkan mereka akan merasa malu jika seandainya mereka dihukum di depan kelas pada waktu pelajaran.

Selanjutnya dari faktor-faktor tersebut menurut Ibu Nina Hidayanti selaku kepala sekolah MTs Hidayatus sholihin yang paling berpengaruh adalah:

Kadang banyak faktor tapi yang paling besar menurut saya itu biasanya keluarga. Kebanyakan dari mereka itu ternyata latar belakang keluarganya broken home atau mungkin perlakuan yang kurang dari keluarga, bapaknya menikah lagi atau ibunya menikah lagi. Sehingga siswa yang keluarganya seperti itu, mencoba untuk mencari perhatian, tapi anak tersebut tidak menyadari bahwa apa yang dilakukan tidak benar. Itu dari salah satu kasus dari mereka akhirnya didatangkan orang tuanya terus kita Tanya bagaimana keadaan di rumah seperti apa. Terus kita juga banyak info dari temanteman, bu Ainun sendiri juga sering didatangi anak-anak. Ini anaknya siapa, keluarganya bagaimana jadi kita dapat menarik

19 Endang Purwanto and Nur Widodo, Perkembangan Peserta Didik (Malang: Universitas Muhammadiyah Malang, 2002). h. 2. kesimpulan bahwa mereka seperti itu karena keluarga broken home, tapi memang tidak semua $^{20}$.

Sedangkan terkait peraturan sekolah tentang sanksi atas pelanggaran yang dilakukan oleh siswa menurut Ibu Ainun Choiriyah dan Ibu Nina mengatakan bahwa sanksi pasti ada para siswa diberikan masingmasing buku peraturan. misalnya saja bawa hp di MTs Hidayatus Sholihin tidak boleh jika ketahuan membawa hp maka akan disita dan tidak akan dikembalikan lagi. Setiap siswa juga sudah diberitahu dengan tanda tangan dibagian belakang buku peraturan serta orang tua juga mengetahui sejak pertemuan pertama masuk siswa baru orang tua sudah didatangkan dan diberitahu dan orang tua menyetujuinya. Setiap hari buku peraturan wajib dibawa meskipun masih banyak siswa yang tidak dibawa. Keberadaan sanksi yang sudah ditetapkan perlu adanya dukungan dari pihak-pihak terkait demi meminimalkan tindakan yang lebih lagi ${ }^{21}$.

\section{Peran Guru dalam Menanggulangi Kenakalan Siswa Kelas VIII Di MTs Hidayatus Sholihin Turus (Gurah)}

${ }^{20}$ Nina Hidayanti, "Kepala Sekolah,” 2018. h.8.

${ }^{21}$ Agus Miftakus Surur, Habib, and Pandi Rais, "The Application Program of the Preparation of the Syllabus and Learning Implementation Plan (RPP) 2013 Curriculum on Teachers Madrasah Ibtidaiyah," Proceeding International Conference on Islamic Education (ICIED) 2, no. Innovations, Approaches, Challenges, and THE Future (2017): h. 246-253. 


\section{Agus Miftakus Surur, Titis Dwi Wulandari, Tanya Fawzi, Adib Zaimatus Shofa}

Berdasarkan hasil wawancara dengan berbagai pihak diantaranya dengan kepala sekolah dan guru aqidah akhlak, dapat dimasukkan kepada pokok persoalan yang pertama mengenai peran guru aqidah akhlak dalam menanggulangi kenakalan siswa kelas VIII MTs Hidayatus Sholihin Turus (Gurah). Menurut Ibu Ainun Choiriyah selaku guru mata pelajaran aqidah akhlak ketika diwawancarai tentang pandangan guru aqidah akhlak dalam menanggulangi kenakalan siswa kelas VIII di MTs Hidayatus Sholihin yaitu:

Biasanya pas pelajaran pas bab e pas saya jadikan contoh tapi kadang tidak semua siswa dapat memahami, tapi yang penting kita sudah menyampaikan, kadang siswa kelas VIII itu merasa tidak punya dosa setelah melakukan pelanggaran, karena memang mereka masih kecil dan bab terkait kenakalan remaja sendiri sebenarnya terdapat pada kelas IX sehingga tidak terlalu mengena.

Berdasarkan keterangan di atas, dapat peneliti simpulkan bahwa pandangan guru dalam menanggulangi kenakalan kelas VIII yaitu ketika proses pembelajaran bab yang terdapat pada mata pelajaran aqidah akhlak yang sedang dipelajari dapat dijadikan contoh bagi siswa dalam kehidupannya sehari-hari. Namun tidak semua siswa memahami tentang bab yang dipelajari. Banyak siswa tidak menyadari atas prilaku yang dilakukan adalah salah.
Sedangkan langkah yang diambil oleh guru aqidah akhlak menurut bu Ainun Choiriyah yaitu:

Karena saya dobel, yaitu guru mapel aqidah akhlak dan wakasis jadi pemanggilan siswa terlebih dahulu, setelah itu pemanggilan orang tua. Sering pemanggilan orang tua bagi yang melanggar aturan dan sering tidak masuk itu juga pemanggilan orang tua karena di buku peraturan juga disebutkan bahwa pabila tidak masuk tanpa izin lebih dari sepuluh kali maka tidak akan naik kelas.

Diantara langkah yang diambil tersebut berdasarkan hasil wawancara dengan bu Ainun Choiriyah dapat disimpulkan bahwa langkah yang paling mendapatkan penekanan lebih yaitu pemanggilan orang tua. Kalau hanya dikasih sanksi saja mereka senang. Misalnya ketika mereka datang terlambat disuruh untuk meminta surat izin, atau membaca istighfar di depan kelas mereka sangat senang dan tidak malah jera.

Sedangkan peran mata pelajaran aqidah akhlak menurut Ibu Ainun Choiriyah sebagai guru aqidah akhlak yaitu:

Kalau perannya sangat penting mbak. Hanya saja tinggal bisa atau tidak anak tersebut menerapkan, karena usia-usia MTs merupakan usia rawan, anak usia tersebut masih ingin untuk coba-coba, sepertinya itu kok enak, biasanya anak-anak seperti itu. Selain karena tempatnya juga dekat dengan Gumul jadi pergaulannya juga luas dan bebas. 
Mulai dari godaan yang banyak pernah terkena miras juga. Seperti kasus kemarin mereka mengaku makan kecubung.

Terkait hal tersebut Ibu Nina Hidayanti selaku kepala sekolah menambahkan yaitu:

Namun anak-anak memakan kecubung karena mereka memang belum tahu kalau kecubung memabukkan. Mereka tahu bahwa itu namanya kecubung tapi tidak tahu efeknya. Jadi, sebenarnya itu bukan termasuk narkoba, jadi hukumannya pun kita meminta bantuan salah seorang ustadz yang bernama gus Najib untuk menerapi anak tersebut. Terapinyapun dalam bentuk ngaji, istighosah langsung ke pondok Mantren. Jadi, diluar jam sekolah. Serta adapula pemanggilan orang tua terkait hal tersebut.

Peristiwa terjadinya siswa memakan kecubung terjadi belum lama yaitu pada tanggal 20 Mei 2018 siswa kelas VIII yang terlibat ada tiga yaitu Rifki Mustofa, Bagus S, Bargi Nasukha. Mereka memakannya karena memang tidak tahu dampak dari kecubung. Mereka hanya tahu bahwa itu kecubung. Pendidikan harus berupaya memberikan pelajaran pada hal-hal yang dapat membahayakan siswa ${ }^{22}$.

Selanjutnya metode yang digunakan dalam pembelajaran aqidah akhlak dengan

22 Nurul Wahyuning Tyas, Dwi Cahyanti Wabula, and Agus Miftakus Surur, "Peran Pengurus Pondok Pesantren Dalam Menanamkan Kedisiplinan Santri," Jurnal Al-Makrifat 3, no. 2 (2018). h. 15. menggunakan metode ceramah serta pengaitan antara bab yang dipelajari dengan kenyataan yang sebenarnya. Sedangkan upaya yang dilakukan oleh guru aqidah akhlak dengan berusaha menjelaskan apa yang dibolehkan dan tidak boleh serta lebih ke pembentukan akhlaknya dan semua guru saling koordinasi untuk mengaitkan semua pelajaran agar menjadi satu kesatuan sesuai dengan kurikulum K13 untuk memudahkan siswa dalam memahami. Siswa juga mempelajai kitab taisiirul kholaq tentang akhlak.

Sedangkan pendapat siswa perempuan terkait aqidah akhlak adalah mudah dipahami dan menjadikan perilaku mereka lebih baik. Serta mereka sepakat bahwa aqidah akhlak memberikan pengaruh terhadap perubahan tingkah laku mereka menjadi lebih baik. Sedangkan pelanggaran yang pernah dilakukan adalah terlambat sekolah. Serta kadang-kadang pulang pada saat jam terakhir.

Sanksi yang diberikan ketika mereka melakukan kesalahan yaitu seperti membaca istighfar di depan kantor bukan di depan kelas. Tidak dilakukan pemanggilan orang tua jika pelanggarannya tidak berat. Serta alasan mereka melakukan pelanggaran seperti terlambat karena mereka kebanyakan dari pondok maka alasannya adalah mereka dating terlambat karena antri mandi. Menurut 


\section{Agus Miftakus Surur, Titis Dwi Wulandari, Tanya Fawzi, Adib Zaimatus Shofa}

mereka guru aqidah akhlak berperan dalam perubahan tingkah laku, karena guru aqidah akhlak selalu mengajarkan akhlak yang baik. Serta menurut mereka guru aqidah akhlak sering memberikan pendidikan karakter setiap proses pembelajaran.

Sedangkan pendapat siswa laki-laki yang bernama Satria Purbaning Dewa dan Imam Zamzami Badrul Kamal setelah diwawancara yaitu menurut mereka aqidah akhlak mengajarkan mereka agar mengetahui bagaimana seharusnya berperilaku. Serta menurut siswa laki-laki bahwa mata pelajaran aqidah akhlak berpengaruh terhadap akhlak mereka yang lebih baik. Misalnya sebelumnya berani terhadap orang tua kemudian setelah mempelajari aqidah akhlak menjadi tidak berani. Sedangkan pelanggaran yang sering dilakukan menurut siswa laki-laki yaitu mereka sering bolos pada waktu pelajaran, merokok, berkelahi, mengendarai motor padahal kalau masih MTs tidak boleh. Alasan berkelahi karena persoalan absen yaitu siswa sering bolos diingatkan tapi tidak mau serta yang mengingatkan juga emosi dan akhirnya menjadi berkelahi.

Terkait sanksi biasanya disuruh untuk membersihkan kamar mandi, membersihkan halaman, berlari mengelilingi Madrasah, jongkok, membaca istighfar di dalam kelas dan sebagainya. Alasan mereka melakukan pelanggaran yaitu karena terpaksa, misalnya tidak boleh bawa motor tapi tetap bawa motor karena terburu-buru sudah hamper terlambat. Sedangkan yang bolos sekolah karena diajak temannya. Sedangkan akalu berkelahi alasannya adalah karena marah menasihati temannya tidak didengarkan.

Menurut mereka aqidah akhlak membantu untuk mengintrospeksi diri agar lebih baik dan merubah sikap-sikap yang buruk. Sedangkan terkait pendidikan karakter menurut mereka guru aqidah akhlak selalu memberikan pendidikan karakter pada saat proses pembelajaran. Sedangkan berdasarkan pengamatan terdapat beberapa siswa yang tidak memakai atribut sekolah dengan lengkap. Sebenarnya mereka sudah diberitahu namun kadang masih tetap saja tidak didengarkan.

\section{Simpulan}

Faktor yang mempengaruhi kenakalan siswa adalah faktor lingkungan dan pengaruh dari teman-temannya. Serta jenis pelanggaran yang sering dilakukan adalah merokok, membolos, pulang sebelum waktunya. Hal tersebut merupakan jenis pelanggaran yang sering dilakukan oleh siswa laki-laki.

Guru aqidah akhlak memiliki peran dalam menanggulangi kenakalan siswa kelas VIII di MTs Hidayatus SholihinTurus (Gurah). Dengan cara pada proses pembelajaran mengaitkan antara bab yang dipelajari dengan kehidupan sehari-hari. Serta saling bekerja sama dengan para guru lainnya 
An-Nisa' : Jurnal Kajian Perempuan \& Keislaman

Vol. 14, No. 2, Oktober 2021

p-ISSN : $2086-0749$

e-ISSN : 2654-4784

tindakan apa yang diambil dan melakukan pemanggilan orang tua apabila terdapat siswa yang melakukan pelanggaran cukup berat. Guru aqidah akhlak selain mengampu mata pelajaran aqidah akhlak juga berperan sebagai wakil kesiswaan (wakasis) sehingga beliau tahu keadaan dari para siswanya.

Penelitian ini masih jauh dari kata sempurna, masih perlu adanya data lebih untuk menghasilkan pembahasan yang lebih spesifik. Keterbatasan waktu menyebabkan peneliti belum dapat menggali data secara menyeluruh dan lengkap. Oleh sebab itu, disarankan adanya penelitian yang lebih luas sehingga dapat memperoleh data secara menyeluruh dan lengkap.

\section{Daftar Pustaka}

Bachri, Bachtiar S. "Meyakinkan Validitas Data Melalui Triangulasi Pada Penelitian Kualitatif.” Jumal Teknologi Pendidikan 1, no. 1 (2010).

Choiriyah, Ainun. Guru Aqidah Akblak.

Yogyakarta: Ruang Kepala Sekolah, 2018.

Depdiknas. Kamus Besar Bahasa Indonesia. Jakarta. Jakarta, 2007.

Hasan Basri. Remaja Berkualitas. Yogyakarta: Mitra Pustaka, 2004.

Hidayanti, Nina. "Kepala Sekolah,” 2018.

Huda, Muhamad Nuril. "Profesionalisme Guru Fiqih Dalam Pembelajaran Dan
Implikasinya Terhadap Sikap Keberagamaan Siswa Di MTs Negeri Kota Manado.” An-Nisa': Jurnal Kajian Perempuan \& Keislaman 13, no. 1 (2020). Husien, Latifah. Profesi Keguruan. Yogyakarta: Pustaka Baru Press, 2016.

Jhon M. Echols, Hassan Shadily. Kamus Inggris-Indonesia. Jakarta: Gramedia Pustaka Utama, 2005.

Kartono, Kartini. Kenakalan Remaja. Jakarta: Raja Grafindo Persada, 2013.

Mustofa. Akblak Tasawnf. Bandung: Pustaka Setia, 2011.

Purwanto, Endang, and Nur Widodo. Perkembangan Peserta Didik. Malang: Universitas Muhammadiyah Malang, 2002.

Rahman, Hibana S. Konsep Dasar Pendidikan Anak Usia Dini. Yogyakarta: PGTKI Press, 2002.

Rodliyah, St. "Implikasi Penanaman NilaiNilai Dasar Agama Islam Terhadap Perilaku Anak Di Taman Kanak-Kanak (TK) 'Al-Amien' Kabupaten Jember." An-Nisa': Jurnal Kajian Perempuan \& Keislaman 13, no. 2 (2020).

Surur, Agus Miftakus. "Peningkatan Kemampuan Khatabah (Public Speaking Skill) Santri Ma'had Darul Hikmah IAIN Kediri." Ijaz, Arabi Journal of Arabic Learning 1, no. 2 (2018). 


\section{- Ragam Strategi Pembelajaran Dilengkapi}

Dengan Evaluasi Formatif. Banten: CV. AA. Rizky, 2020.

Surur, Agus Miftakus, Habib, and Pandi Rais.

"The Application Program of the Preparation of the Syllabus and Learning Implementation Plan (RPP) 2013 Curriculum on Teachers Madrasah Ibtidaiyah." Proceeding International Conference on Islamic Education (ICIED) 2, no. Innovations, Approaches, Challenges, and THE Future (2017): 246-253.

Surur, Agus Miftakus, Abdul Hafid Rosyidi, Yanuar Adi Prasetia, Khozinatul Asrori, and Latifatul Azizah. "Problematika Pembelajaran Siswa MTs Sunan Gunung Jati (Studi Kasus Latar
Belakang Siswa Menghadapi Ujian)." Edudeena 1, no. 1 (2018): 13-32.

Surur, Agus Miftakus, Eka Septiarini, and Ayu Yulia Trianawati. "Upaya Menanamkan Nilai Religius Siswa Di MAN Kediri 1 Kota Kediri Melalui Ekstrakurikuler Keagaman Tahfidz AlQur'an." Jurnal Pendidikan Agama Islam XV, no. 1 (2018).

Syah, Muhibbin. Psikologi Pendidikan Dengan Pendekatan Baru. Bandung: Remaja Rosdakarya, 2010.

Tyas, Nurul Wahyuning, Dwi Cahyanti Wabula, and Agus Miftakus Surur. "Peran Pengurus Pondok Pesantren Dalam Menanamkan Kedisiplinan Santri." Jurnal Al-Makrifat 3, no. 2 (2018). 